\title{
Evaluating the Efficiency of Migration Regimes and Their Role in the Progress of Common European Labor Market
}

\author{
Ai Huu Tran, Nguyen Le Thi Minh, Denis Ushakov
}

\begin{abstract}
The key objective of this research is to test the adequacy rate of the current migration regime for further scientific and methodological grounding of the principles and directions in modernization of migration policies in the $E U$. The article also defines the efficiency of the contemporary migration policy along with the factors and preconditions for its improvement. The author also explains the notion of migration regime adequacy as the major precondition for efficient management of migration flows. Then the author suggests an original methodology for evaluation of adequacy of the contemporary migration regimes in the $\mathrm{EU}$ using the available statistical information and own theoretical grounding of the migration regime adequacy as a factor of migration policy efficiency. Author's recommendations are provided concerning the directions in using this methodology for testing the adequacy of other migration regimes.

Finally, the article tests the hypotheses concerning the interdependence between the efficiency of migration policy in the selected contemporary countries and the size and probability of economic return with the size and risk of a probably damage from further development of the international labor migration. Overall, we can conclude that when a country is following the priorities of own development and is responding to world markets' challenges at the same time, its migration policy can be called adequate when it is differentiated enough, selective and sufficiently strict.
\end{abstract}

Keywords: international migration of the labor force; labor immigration; migration regime; migration policy; adequacy; the European Union.

\section{INTRODUCTION}

Contemporary dynamics of the world economy is predetermined primarily by globalization of production and distribution processes which is manifested, in the first place, through rapid distribution of transnational production-distribution systems and corporations' transition into the only truly competitive type of global entrepreneurship. Consumer preferences are also being universalized, thus, the whole systems of consumption and trade are being universalized as well. Another no least important factor for the progress of the world economy is globalization of the production markets and formation of the related international institutes (world financial market, global market of technologies, international legal basis for information exchange between countries and so on). All of these trends are equally applicable to the labor force market as well.

Despite the widely spread thought that the migration policy of Europe is harsh and restrictive, the inflow of labor migrants to the EU countries is only growing all the time (even under the conditions of economic recession and growth of internal unemployment in these countries).

The central issue of any migration policy is maximization of economic profit and return from using foreign labor force. At the same time, the related government authorities should not forget about a variety of potential risks and damages from migration, both short- and long-term.

The implemented migration policy can be called truly efficient when the following priorities are strictly followed:

- growth of the national economic system caused by labor immigration should be kept balanced;

- national labor market should be closely monitored and balanced whenever necessary;

- attraction of foreign labor should go in parallel to attraction of foreign investments into the country;

- all possible damages from foreign labor immigration should be reduced to the minimum;

- implementation of the national migration policy should be cost effective in terms of administration spending;

- illegal labor immigration should be strictly prevented;

- the final aim is to prevent, by all means, the destabilization of the internal labor market.

Revised Version Manuscript Received on 16 September, 2019.

* Correspondence Author

Ai Huu Tran, Van Hien University, Ho Chi Minh City, Vietnam e-mail: aith@vhu.edu.vn

Nguyen Le Thi Minh, Van Hien University,Ho Chi Minh City, Vietnam e-mail: nguyenltm@vhu.edu.vn

Denis Ushakov, International college, Suan Sunandha Rajabhat University, Bangkok, Thailand

e-mail: denis.us@ssru.ac.th 
Table 1. Key directions and instruments in modernization of migration policies in the EU countries [5, 6]

\begin{tabular}{|c|c|c|c|}
\hline$\#$ & $\begin{array}{l}\text { Direction in } \\
\text { modernization of the } \\
\text { national migration policy }\end{array}$ & $\begin{array}{l}\text { Instruments used in the course of modernization in the field } \\
\text { of state regulation over migration processes }\end{array}$ & $\begin{array}{l}\text { Countries actively using } \\
\text { these instruments }\end{array}$ \\
\hline \multirow[t]{10}{*}{1} & \multirow{10}{*}{$\begin{array}{l}\text { Stimulation of foreign } \\
\text { intellectuals' inflow in the } \\
\text { country }\end{array}$} & - the system of quotas for highly qualified professionals & $\begin{array}{l}\text { Italy, Germany, Ireland, } \\
\text { the Netherlands }\end{array}$ \\
\hline & & $\begin{array}{l}\text { - the system of scores used to assess the candidates for labor } \\
\text { migration }\end{array}$ & UK \\
\hline & & - state programs supporting labor migration of intellectuals & UK, Italy, Ireland \\
\hline & & $\begin{array}{l}\text { - simplified order of getting work permits, residence permits } \\
\text { and citizenship for highly qualified labor immigrants }\end{array}$ & France, Germany \\
\hline & & $\begin{array}{l}\text { - a special type of research visas for separate categories of } \\
\text { highly qualified migrants }\end{array}$ & EU as a whole \\
\hline & & $\begin{array}{l}\text { - simplified procedures of hiring foreign highly qualified } \\
\text { professionals }\end{array}$ & $\begin{array}{l}\text { Denmark, Germany, } \\
\text { Netherlands, UK }\end{array}$ \\
\hline & & $\begin{array}{l}\text {-attracting more international students into the country by } \\
\text { means of granting university graduates the employment } \\
\text { rights }\end{array}$ & $\begin{array}{l}\text { Germany, Sweden, UK, } \\
\text { France, Italy }\end{array}$ \\
\hline & & $\begin{array}{l}\text { - creation of specialized zones for innovations' } \\
\text { development, granting them tax and other preferences }\end{array}$ & $\begin{array}{l}\text { Sweden, Denmark, } \\
\text { Belgium, Ireland }\end{array}$ \\
\hline & & $\begin{array}{l}\text { - introducing repatriation programmes for highly qualified } \\
\text { labor migrants }\end{array}$ & Norway, Finland \\
\hline & & - preferential employment for foreign university lecturers & Finland, Norway \\
\hline 2 & $\begin{array}{l}\text { Encouraging business } \\
\text { immigration }\end{array}$ & $\begin{array}{l}\text { - welcoming investors and business people who would like } \\
\text { to start business in the country }\end{array}$ & UK \\
\hline 3 & $\begin{array}{l}\text { Welcoming } \\
\text { temporary/seasonal labor } \\
\text { migration }\end{array}$ & $\begin{array}{l}\text { - establishing bilateral cooperation between donor countries } \\
\text { and agricultural/tourism sectors of the recipient country }\end{array}$ & Germany, UK \\
\hline \multirow[t]{4}{*}{4} & \multirow[t]{4}{*}{$\begin{array}{l}\text { Rational schemes of } \\
\text { family reunions }\end{array}$} & $\begin{array}{l}\text { - limiting the list of relatives with the right for a family } \\
\text { reunion visa }\end{array}$ & Italy \\
\hline & & $\begin{array}{l}\text { - increased requirements to the income level of a sponsoring } \\
\text { person }\end{array}$ & $\begin{array}{l}\text { the Netherlands, } \\
\text { Denmark, France }\end{array}$ \\
\hline & & $\begin{array}{l}\text {-defining in advance the opportunities of employment and } \\
\text { socialization of migrant's family members }\end{array}$ & France, Italy \\
\hline & & $\begin{array}{l}\text { - increasing the minimum duration of migrant's stay before } \\
\text { he/she gets the right for family reunion application }\end{array}$ & France \\
\hline \multirow[t]{3}{*}{5} & \multirow[t]{3}{*}{$\begin{array}{l}\text { Limitations on asylum } \\
\text { applications }\end{array}$} & $\begin{array}{l}\text { - a person waiting for determination/redetermination of an } \\
\text { asylum decision cannot stay on the territory of the country }\end{array}$ & Germany \\
\hline & & $\begin{array}{l}\text { - reduced volume of social payments for the people waiting } \\
\text { for a decision on asylum }\end{array}$ & Germany \\
\hline & & $\begin{array}{l}\text { - the policy of "closed doors" and collective responsibility } \\
\text { for the policies regulating the inflow of refugees }\end{array}$ & $\begin{array}{l}\text { EU as a whole } \\
\text { Switzerland }{ }^{\text {nd }}\end{array}$ \\
\hline
\end{tabular}




\begin{tabular}{|c|c|c|c|}
\hline & & $\begin{array}{l}\text { - countermeasures in case of repeated requests for asylum } \\
\text { and also in case of simultaneous requests on the same } \\
\text { submitted to several EU countries }\end{array}$ & $\begin{array}{l}\text { EU as a whole + } \\
\text { Switzerland }\end{array}$ \\
\hline \multirow[t]{5}{*}{6} & \multirow[t]{5}{*}{$\begin{array}{l}\text { Fighting illegal labor } \\
\text { migration }\end{array}$} & $\begin{array}{l}\text { - strict requirements to all applicants for working, business, } \\
\text { student, immigration and tourism visas }\end{array}$ & EU as a whole \\
\hline & & $\begin{array}{l}\text {-digitalization of border control (checking biometrical data, } \\
\text { dactyloscopy, screenings) }\end{array}$ & $\begin{array}{l}\text { EU as a whole + Iceland } \\
\text { and Norway }\end{array}$ \\
\hline & & $\begin{array}{l}\text { - strengthening of state borders; widening the zone which } \\
\text { can be subject to no-permit surveillance }\end{array}$ & Germany \\
\hline & & - modernization of the system issuing work permits & EU as a whole \\
\hline & & $\begin{array}{l}\text { - signing bilateral agreements of cooperation with border } \\
\text { and migration services of the neighbouring countries }\end{array}$ & Germany, Italy, France \\
\hline
\end{tabular}

Taking into account the current dynamics and trends in labor migration, our analysis of the migration policies in the European Union allows outlining the following directions in modernization of the state regulatory system over immigration processes: stimulating the inflow of intellectuals and other highly qualified labor migrants; encouraging business and investment types of labor migration; active development of seasonal immigration; rationalization of the family reunion schemes; introducing limitations on granting asylum; counteracting and preventing illegal labor immigration. Structural components and examples of the related measures are presented in Table 1 as per each direction.

\section{MAIN FOCUS OF THE STUDY}

Using this information and taking into account the legal infrastructure of migration policy in European states we can now move to evaluating the adequacy of national migration regimes in Europe. The adequacy will be measured as per the requirements of the globalizing world and also as per key direction in modernization of migration policies in the countries of the so-called Old World (all of them also mentioned in Table 1).

Evaluation of the adequacy of national migration regimes in the EU-28 + Turkey has been carried out on the basis of testing migration regimes of each of these countries following the list of questions presented in Table 2.
For each answer the national migration regime gets a certain score. Then the final sum of scores defines the level of adequacy of the migration regime.

All test questions and their further evaluation follows a certain logic which probably requires an explanation. The first group of questions covers the issues related to documents required for legal foreign labor immigration in the countries in question. It evaluates the overall number of documents any foreigner would need for legal employment and indirectly shows how complex/easy is the process of legalization in a country.

For example: if a country has official visas for seasonal works (for specific sectors such as agriculture, tourism and/or hospitality), it tends to be overall more liberal in relation to all labor immigrants since only a minimum list of supporting documents is required to access the national labor market in this case. Labor migrants usually get seasonal visas before they cross the physical border, thus, once they arrive - they can get to work straight at once, the only requirement being that they have to leave in 6 months since the first day [8].

Document requirements to permanent workers is more strict, of course. Working visas should be usually obtained before crossing the physical border of the country, while work permit can be obtained when a migrant is already in the country. Residence permit requires the migrant to be in the country, moreover, the migrant has to demonstrate a certain level of knowing the local language and also pay a rather high residence permit fee.

Table 2. Tested items for evaluation of migration regimes in the EU countries

$[10,11]$

\begin{tabular}{|l|l|c|c|}
\hline$\#$ & \multicolumn{1}{|c|}{ Tested item } & $\begin{array}{c}\text { Scores for } \\
\text { YES }\end{array}$ & $\begin{array}{c}\text { Scores } \\
\text { for NO }\end{array}$ \\
\hline 1.1 & $\begin{array}{l}\text { Does the migration regime of the country allow more than one type of } \\
\text { residence permit and more than one type of work permit? }\end{array}$ & 3 & 0 \\
\hline 1.2 & $\begin{array}{l}\text { Is residence permit the only way for a foreigner to get legal access to the } \\
\text { national labor market? }\end{array}$ & 0 & 2 \\
\hline 1.3 & $\begin{array}{l}\text { Do foreign workers have access to the local market only when they have } \\
\text { residence permit and work permit? }\end{array}$ & S & $\begin{array}{l}\text { Published By: } \\
\text { Blue Eyes Intelligence Engineering } \\
\text { \& Sciences Publication }\end{array}$ \\
\hline
\end{tabular}




\begin{tabular}{|c|c|c|c|}
\hline 1.4 & Does the country officially have visas for seasonal work? & 5 & 0 \\
\hline 1.5 & $\begin{array}{l}\text { Does the national migration regime have the procedure of obtaining a green } \\
\text { card? }\end{array}$ & 6 & 0 \\
\hline 1.6 & $\begin{array}{l}\text { Does the residence permit mean that a foreigner has the right to buy real } \\
\text { estate? }\end{array}$ & 5 & 0 \\
\hline 2.1 & $\begin{array}{l}\text { Is work permit the only requirement for a family reunion application? } \\
\text { (meaning, no additional requirements on wage minimum etc.) }\end{array}$ & 6 & 0 \\
\hline 2.2 & $\begin{array}{l}\text { Does the procedure of family reunion requires a certain minimum wage from } \\
\text { the migrant? }\end{array}$ & 0 & 5 \\
\hline 3.1 & $\begin{array}{l}\text { Is the work permit attached to a specific employer but not to a specific type } \\
\text { of activity? }\end{array}$ & 0 & 5 \\
\hline 3.2 & Can work permit be longer than 1 year? & 3 & 0 \\
\hline 3.3 & Is it possible to prolong work permit (not issuing the whole new document)? & 4 & 0 \\
\hline 3.4 & $\begin{array}{l}\text { Do migration rules include the requirement on minimum wage for getting } \\
\text { work permit? }\end{array}$ & 0 & 5 \\
\hline 3.5 & $\begin{array}{l}\text { Does qualification of an applicant serve as the key basis for getting work } \\
\text { permit? (as opposed to the sector of future work) }\end{array}$ & 0 & 5 \\
\hline 4.1 & $\begin{array}{l}\text { Do students have the right for further employment and changing their student } \\
\text { visa for work permit? }\end{array}$ & 3 & 0 \\
\hline 4.2 & Do students have the right to work part time, combining work with studies? & 5 & 0 \\
\hline 5.1 & $\begin{array}{l}\text { Does migration policy of the country include the quota for foreign labor } \\
\text { migrants? }\end{array}$ & 0 & 2 \\
\hline 5.2 & $\begin{array}{l}\text { Do residents of other EU countries, working in this country, have to go } \\
\text { through registration for getting work permit? }\end{array}$ & 0 & 3 \\
\hline 5.3 & $\begin{array}{l}\text { Does migration policy of the country has a special quota for foreign labor } \\
\text { migrants that are not residents of the EU but are temporary staying on the } \\
\text { territory of other EU countries? }\end{array}$ & 0 & 2 \\
\hline 5.4 & $\begin{array}{l}\text { Does the country have a separate quota for foreign migrants arriving to the } \\
\text { country on family reunion programs? }\end{array}$ & 0 & 5 \\
\hline 5.5 & Does the country has quotas for highly qualified labor migrants? & 0 & 5 \\
\hline 6.1 & $\begin{array}{l}\text { Does the migration policy of the country prioritizes labor migrants from the } \\
\text { countries that already have bilateral migration agreements with this country? }\end{array}$ & 0 & 5 \\
\hline 6.2 & $\begin{array}{l}\text { Does this country has agreements on migration cooperation with the } \\
\text { countries outside the EU? }\end{array}$ & 5 & 0 \\
\hline 6.3 & $\begin{array}{l}\text { Does the country officially have the problem of foreign laborers being } \\
\text { discriminated? }\end{array}$ & 0 & 10 \\
\hline 6.4 & $\begin{array}{l}\text { Can the ownership of a commercial entity (self-employment) serve as the } \\
\text { basis for getting work permit? }\end{array}$ & 5 & 0 \\
\hline
\end{tabular}

Liberal nature/restrictive nature/adequacy of a migration regime is - generally speaking - defined by the mandatory package of documents needed to start working in a country: a) working visa only; b) working visa and work permit; c) working visa, work permit and also residence permit.

The second group of questions describes the policy of a state in relation to family 
reunions of labor migrants: what documents are required from a migrant to start the family reunion procedure, are there any additional documents to regulate the process of family reunion, are there any quotas on families etc.

The third group of questions covers the process of getting a work permit: general requirements; affiliation to a particular employer or to a whole industry; requirements to qualifications, age, health; expectations on a potential wage; duration of a work permit; opportunities for prolonging work permit (the same permit, not getting a new one).

The fourth group of questions evaluates the adequacy of country's migration policy in relation to international students who are actually potential highly qualified labor migrants too. In particular, this group of questions assesses the students' chances to be part-time employed and their opportunities for further employment upon graduation.

The fifth group of questions covers quotas as an instrument of legal regulation over labor immigration. It analyzes several types of quotas on employment of foreign migrants: general quota for all foreign migrants; quota for foreign migrants who are residents of other EU countries; quotas for foreign migrants who are not citizens of any EU country but are temporary legally living in some EU member country; quota for highly qualified labor migrants from third countries, outside the EU; and finally, a special quota for labor migrants arriving to the country on family reunion programs. Obviously, availability of several types of quotas in a country strengthens the restrictive and selective nature of its migration policy.

Finally, the last part of the questions is dedicated to the officially stated priorities of the migration policies of the EU members: for example, the officially declared discriminatory principles (when conditions for labor migration depend on the origin country); priority given to labor migrants from the countries that have bilateral agreements of cooperation with this country; opportunities for simplified legalization for foreign investors and also for people interested in doing business locally.

For our testing estimations we have used statistical and descriptive information from the expert groups of the European Union and also from the national authorities regulating labor migration in the EU-28 countries + Turkey $[1,2,3,4,7,9,12,13]$. Results of our research are presented in Table 3.

Table 3. Adequacy of national migration policies in the EU countries

\begin{tabular}{|c|c|c|c|c|c|}
\hline$\#$ & Country & $\begin{array}{c}\text { Indicator of } \\
\text { national migration } \\
\text { policy adequacy }\end{array}$ & $\#$ & Country & $\begin{array}{c}\text { Indicator of national } \\
\text { migration policy } \\
\text { adequacy }\end{array}$ \\
\hline 1 & Germany & 92 & 16 & Turkey & 51 \\
\hline 2 & France & 80 & 17 & Malta & 49 \\
\hline 3 & Poland & 67 & 18 & Greece & 46 \\
\hline 4 & Czech Rep. & 66 & 19 & Slovenia & 46 \\
\hline 5 & Ireland & 66 & 20 & Spain & 46 \\
\hline 6 & UK & 62 & 21 & Slovakia & 43 \\
\hline 7 & Latvia & 59 & 22 & Austria & 41 \\
\hline 8 & Portugal & 58 & 23 & Estonia & 40 \\
\hline 9 & Finland & 56 & 24 & Lithuania & 37 \\
\hline 10 & Luxemburg & 56 & 25 & Hungary & 33 \\
\hline 11 & Netherlands & 56 & 26 & Croatia & 32 \\
\hline 12 & Bulgaria & 55 & 27 & Cyprus & 32 \\
\hline 13 & Denmark & 52 & 28 & Belgium & 29 \\
\hline 14 & Norway & 52 & 29 & Romania & 28 \\
\hline 15 & Italy & 47 & & Average value & 51 \\
\hline
\end{tabular}

Once we've calculated the scores for adequacy/inadequacy of the migration regimes in the analyzed countries, we get the final results for migration regime adequacy indicators (see Table 3 ).
Data in this table shows that the most adequate to current economic development in Europe are the migration policies of Germany, France and Poland. At the same time, the policies of, for example, 
Romania, Belgium or Cyprus are among the least adequate to the requirements of the current economic stage. This means that policies of the latter countries require immediate modernization.

In 6 EU countries (Germany, France, Poland, Czech Republic, Ireland and the UK) the quality of migration policy is much higher as compared to the European average value. At the same time, in other 7 countries (Lithuania, Hungary, Croatia, Cyprus, Belgium and Romania) the situation is exactly the opposite: the adequacy of their migration policies is significantly lower than the European average level.

\section{Conclusions}

Implementation efficiency of the contemporary migration policy depends primarily upon two factors - the growth of economic return (due to reorientation of immigration flows in favor of highly qualified professionals, development of investment \& business immigration, stabilization and balancing of the national labor market) and reduction of the potential damage from immigration (counteracting illegal labor migration and destabilization of national labor market).

The most adequate to the current modernization requirements of a European migration policy would be a migration regime which is differentiated to the very maximum and selective to all potential labor migrants. At the same time, it should be restrictive enough in relation to illegal migration and illegal employment of foreigners.

For evaluation of the migration regimes' adequacy in the EU countries we have offered a methodology which is based on testing migration regimes on 24 issues which are describing the national migration policy in terms of economic value from labor migration and reduction of negative influences from migration processes on the ongoing socioeconomic development of the country.

The carried out evaluation proves high level of differentiation in the adequacy levels across the EU (+ Turkey). In other words, countries across Europe demonstrate very different levels of efficiency, and at least seven of them have rather inadequate migration policies which require immediate modernization and reform.

The author's methodology of measuring the adequacy of a migration regime can be used further in the course of determining the efficiency of national regulation over migration flows in the countries - members of other regional integrations and also for measuring the efficiency of migration flows management at the supranational level.

\section{REFERENCES}

[1] Economist Intelligence Unit (2014). Estimating potential labor shortage and supply in the European Economic Area. A report for Home Office Advisory Committee.

[2] Estruch-Puertas, E. \& Zupi, M. (2009). Assessment of data sources and methodology development for measuring foreign labor requirements in the Russian Federation.

[3] Satisfying labor demand through migration. Synthesis report (2018). International Labor Organization. European Migration Network. .

[4] International Migration Outlook, SOPEMI (2018). Regional determinants of localization of recent immigrants across OECD regions.

[5] Arkhipov, A., Ushakov, D. (2018). Functional effectiveness and modern mechanisms for national urban systems globalization: The case of Russia. In: E-Planning and Collaboration: Concepts, Methodologies, Tools, and Applications, IGI-global.
[6] International Organization for Migration (IOM). (2018). Migration, employment and labor market integration policies in the European Union. IOM LINET.

[7] Jacoby, T. (2013). Selecting for integration - What role for a point system? (Policy Brief). German Marshall Fund of the United States.

[8] Kahanec, M. \& Zimmermann, K. (2011). High-skilled immigration policy in Europe. Institute for the Study of Labor (IZA).

[9] Labour shortages and migration policy (2012). Edited by Platonova A. and Urso G. International Organization of Migration, Belgium.

[10] Ushakov, D., Chich-Jen, S. (2018). Global economy urbanization and urban economy globalization: Forms, factors, results. In: E-Planning and Collaboration: Concepts, Methodologies, Tools, and Applications, IGI-global.

[11] Labor shortages and the need for immigrants: A review of recent studies (2009). Organization for Economic Co-operation and Development (OECD).

[12] Ushakov, D. (2015). Labor immigration in dynamics of European Union's national economic progress: macroeconomic analysis and basic indicators. Actual Problems of Economics, 3.

[13] Ushakov, D., Rubinskaya, E. (2018). Reforming of the state immigration policy in the context of globalization: On the example of Russia. In: Immigration and the Current Social, Political, and Economic Climate: Breakthroughs in Research and Practice. IGI-global. 